\title{
Inclusion Body Fibromatosis
}

National Cancer Institute

\section{Source}

National Cancer Institute. Inclusion Body Fibromatosis. NCI Thesaurus. Code C3456.

A rare benign neoplasm arising from the soft tissues of the digits, in young children. It is

characterized by the presence of fibroblastic spindle cells, and intracytoplasmic eosinophilic spherical inclusions. 